\title{
FABRICATION OF COLLAGEN HYDROLYSATE NANOFIBERS BY THE ELECTROSPINNING METHOD
}

\section{Meruyert KAYGUSUZ}

Pamukkale University, Denizli Vocational School of Technical Sciences, Denizli, Turkey, meruyertk@pau.edu.tr

Received: 29.07.2019

Accepted: 02.12.2019

https://doi.org/10.24264/Ifj.19.4.8

FABRICATION OF COLLAGEN HYDROLYSATE NANOFIBERS BY THE ELECTROSPINNING METHOD

ABSTRACT. Nanotechnology is a ground-breaking technology which has found applications on many areas of daily life. Fibers with nanometer diameters are the most suitable candidates for a large number of applications since they have high surface area to volume ratio and different surface characteristics. Among the various nanofiber production techniques, the most advanced and efficient is the electrospinning technique. In our study, nanofibers were obtained from collagen hydrolysate by the electrospinning method. For this purpose, collagen hydrolysate was dissolved at different concentrations in 2,2,2-trifluorethanol and stirred for six hours at room temperature. The turbidity, viscosity, conductivity and $\mathrm{pH}$ of the solutions were determined. According to the results obtained, it was observed that viscosity and conductivity values rose as the amount of collagen hydrolysate increased. Nanofibers of collagen hydrolysate with $103 \mathrm{~nm}$ and $384 \mathrm{~nm}$ obtained by the electrospinning method were examined by SEM, and their morphological characteristics were discussed.

KEY WORDS: electrospinning, collagen hydrolysate, nanofiber, leather

\section{FABRICAREA NANOFIBRELOR DIN HIDROLIZAT DE COLAGEN PRIN METODA ELECTROSPINNING}

REZUMAT. Nanotehnologia este o tehnologie de ultimă oră, care a găsit aplicaţii în multe domenii ale vieţii de zi cu zi. Fibrele cu diametru de ordin nanometric sunt cele mai potrivite candidate pentru un număr mare de aplicaţii, deoarece au raport suprafaţă/volum ridicat şi caracteristici diferite ale suprafeţei. Printre diferitele tehnici de producție a nanofibrelor, cea mai avansată şi eficientă este tehnica electrospinning. În studiul nostru, s-au obţinut nanofibre din hidrolizat de colagen prin metoda electrospinning. În acest scop, hidrolizatul de colagen a fost dizolvat la diferite concentraţii în 2,2,2-trifluoretanol şi agitat timp de şase ore la temperatura camerei. S-au determinat turbiditatea, vâscozitatea, conductivitatea şi pH-ul soluţiilor. Conform rezultatelor obţinute, s-a observat că valorile vâscozităţii şi conductivităţii au crescut odată cu creşterea cantităţii de hidrolizat de colagen. Nanofibrele din hidrolizat de colagen cu $103 \mathrm{~nm}$ şi $384 \mathrm{~nm}$ obţinute prin metoda electrospinning au fost examinate prin SEM şi s-au discutat caracteristicile morfologice ale acestora.

CUVINTE CHEIE: electrospinning, hidrolizat de colagen, nanofibră, piele

\section{LA FABRICATION DE NANOFIBRES D'HYDROLYSAT DE COLLAGÈNE PAR LE PROCÉDÉ D’ÉLECTROFILAGE}

RÉSUMÉ. La nanotechnologie est une technologie révolutionnaire qui a trouvé des applications dans de nombreux domaines de la vie quotidienne. Les fibres de diamètre nanométrique sont les candidats les plus appropriés pour un grand nombre d'applications car elles ont un rapport surface/volume élevé et des caractéristiques de surface différentes. Parmi les différentes techniques de production de nanofibres, la plus avancée et la plus efficace est la technique d'électrofilage. Dans notre étude, les nanofibres ont été obtenues à partir d'hydrolysat de collagène par la méthode d'électrofilage. Dans ce but, l'hydrolysat de collagène a été dissous à différentes concentrations dans le 2,2,2-trifluoréthanol et agité pendant six heures à température ambiante. La turbidité, la viscosité, la conductivité et le pH des solutions ont été déterminés. Selon les résultats obtenus, on a observé que les valeurs de viscosité et de conductivité augmentaient à mesure que la quantité d'hydrolysat de collagène augmentait. Les nanofibres d'hydrolysat de collagène à $103 \mathrm{~nm}$ et $384 \mathrm{~nm}$ obtenues par la méthode d'électrofilage ont été examinées par SEM, et leurs caractéristiques morphologiques ont été discutées.

MOTS CLÉS : électrofilage, hydrolysat de collagène, nanofibre, cuir

\footnotetext{
* Correspondence to: Meruyert KAYGUSUZ, Pamukkale University, Denizli Vocational School of Technical Sciences, Denizli, Turkey, meruyertk@ pau.edu.tr
} 


\section{INTRODUCTION}

Nanotechnology is a ground-breaking technology which has found applications in many areas of daily life. The basic reason for the rapidly growing interest in nanotechnology is that studies of nanotechnology have shown materials to have different characteristics at very small dimensions, thus completing deficiencies in basic knowledge. Fibers with nanometer diameters are the most suitable candidates for a large number of applications since they have high surface area to volume ratio and different surface characteristics and have shown much better mechanical performance than materials in other forms in terms of hardness and mechanical strength [1].

Nanofibers fabrication can be performed by bicomponent extrusion, template synthesis, self-assembly, phase separation, melt-blowing, drawing, centrifugal spinning and electrospinning [2]. However, the electrospinning method is easy and cheap, and fibers can be produced from many polymers, making it the most flexible and most preferred method [3]. In the electrospinning method, a polymer solution or a molten polymer is exposed to a high voltage, which gives it an electric charge. A jet of the polymer solution from a fine nozzle is directed towards a target with the opposite charge, placed opposite the nozzle. During this process the solvent evaporates, or if molten polymer is being used it begins to solidify. The jet of polymer is scattered as very fine fibers, and in this way fibers with a diameter on the nano scale can be obtained [4-6].

A large number of studies on the production of nanofibers by the electrospinning method deal with the use of many different polymers for various purposes. These studies have shown that polyurethane $[7,8], \mathrm{PVA} /$ sodium alginate [9] and PEO/sodium alginate [10], chitin [11], cellulose [12], PVA [13], polyacrylic acid [14], PMMA [15], polystyrene [16], nylon-6 [17] and all other polymers which can be used in nanofiber production techniques are suitable for electrospinning.

The main source of natural polymer collagen is the skins of various animals. Among the fibrous proteins in the skin structure, the amount of collagen is $98 \%$ [18]. Collagen hydrolysate $(\mathrm{CH})$ is produced by the controlled hydrolysis of collagen and consists of a mixture of polypeptides that are dispersed by molecular weight [19]. CH shows technological advantages such as good resolution, heat stability and high resistance to precipitation with metal ions or $\mathrm{pH}$ [20]. It is used in different fields such as food, medicine, pharmaceuticals, cosmetics and biomaterials due to its bioactivity, biocompatibility and penetration as well as its excellent digestibility and high consumer tolerance [19].

Today, as well as intense research into nanofibers, more importance is being accorded to studies on developing new products and materials containing collagen to be used for different purposes, in order to increase the opportunities for making use of collagen-based products. In a scan of the literature, it was found that gelatin, a biopolymer with known advantages for use especially in the biomedical field [21, 22], collagen [23-25], and mixtures of collagen with other polymers had been used in a number of studies of electrospinning [26-29]. Collagen and chitin derivate nanofibers were obtained by electrocapillary, electrocentrifugal, Nanospider ${ }^{\mathrm{TM}}$ methods [30]. Also, it was found that in these studies, different cross-linkers or hardening polymers had been used in the production of collagen-based nanofibers. In this study therefore, the topic of the production of collagen hydrolysate nanofibers by the electrospinning method without the use of crosslinkers or hardening polymers was considered, and the morphological characteristics of the collagen hydrolysate nanofibers obtained were discussed.

\section{MATERIALS AND METHODS}

\section{Materials}

Collagen hydrolysate was provided by Sigma-Aldrich and the TFE (2,2,2-trifluorethanol) used as a solvent was supplied by Fluka (Germany).

\section{Method}

\section{Setting up the Apparatus for Electrospinning}

The main apparatus used in this study was an electrospinning unit used in the production of nanofibers. The most important parts of this 
were the feed unit and spinning collector cylinder, designed by the Küçüker company (Turkey) with the support of the Scientific Research Projects Coordinatorship of Pamukkale University, a high voltage source (Simco, UK), and a syringe perfusion pump (New Era 1100, USA), obtained from the distributor companies.

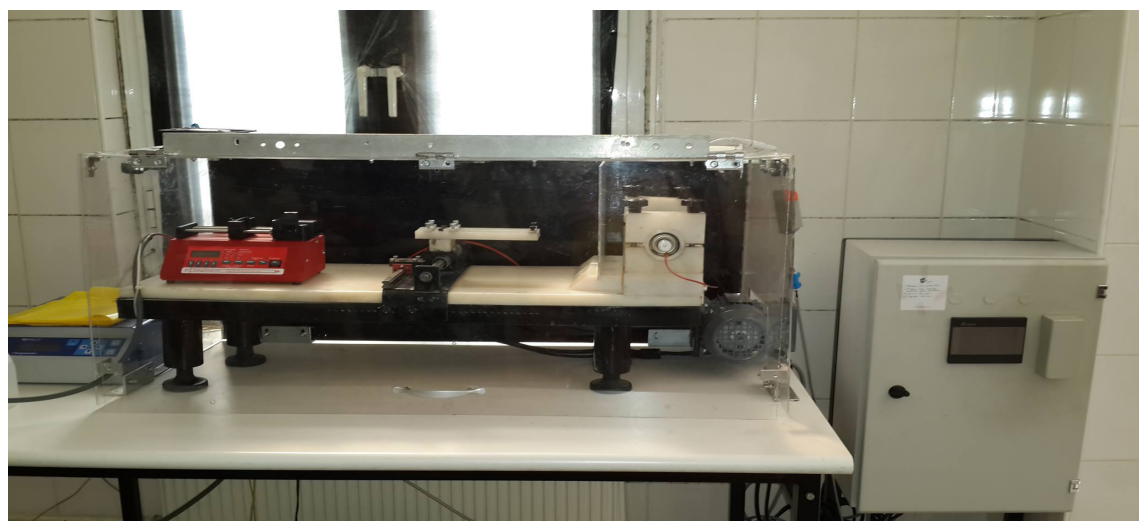

Figure 1. Electrospinning apparatus used in nanofiber production

Preparation of Solution, Optimization and Nanofiber Production

Collagen hydrolysate $(\mathrm{CH})$ at various concentrations $(10 \%, 15 \%, 20 \%, 25 \%, 30 \% \mathrm{w} / \mathrm{v})$ was dissolved in 2,2,2-trifluoroethanol (10\% v/v) and stirred for six hours at room temperature (relative humidity $40 \%$ ). The resulting solution was loaded into a plastic syringe (Ayset Plastik, Turkey) of volume $10 \mathrm{~mL}$ and diameter $0.9 \mathrm{~mm}$ with a metal syringe needle tip, and optimization of the parameters for the production of nanofibers by electrospinning was carried out at room temperature.

First of all, the distance between the end of the syringe and the collector plate were examined in the range of $8-12 \mathrm{~cm}$. The parameters in the electrospinning process to obtain nanofibers of the voltage applied and the flow rate of the feed solution were accepted as experimental variables. In order to determine the effect on nanofiber yield of these parameters, different voltages and different flow rates were applied for concentrations of collagen hydrolysate (Table 1). Optimization studies showed that optimum values were a concentration of $20 \%, 25 \%$ and $30 \% \mathrm{w} / \mathrm{v}$ of $\mathrm{CH}$, a stirring time of 6 hours, a voltage value of $20 \mathrm{kV}$ and a flow rate of $0.8 \mathrm{~mL} /$ hour. The distance between the metal tip of the syringe and the collector plate was determined as $12 \mathrm{~cm}$. The duration of all experiments was set at 120 and 180 minutes (for obtaining thicker nanofiber mats).
Table 1: Electrospinning parameters

\begin{tabular}{cc}
\hline \multicolumn{2}{c}{ Electrospinning parameters } \\
\hline Different voltages, $\mathrm{kV}$ & $13,15,17,20$ \\
Flow rates, $\mathrm{mL} / \mathrm{h}$ & $0.8,1.0,1.5,2.0$ \\
Distance, $\mathrm{cm}$ & $8,10,12$ \\
Duration, $\mathrm{min}$ & 120,180 \\
\hline Solution parameters & \\
\hline Concentration, \% (w/v) & $10,15,20,25,30$ \\
\hline
\end{tabular}

\section{Characterization of Solution}

The $\mathrm{pH}$ measurements of the working solutions were performed using a digital $\mathrm{pH}$ meter (WTW, Germany). The viscosity of the working solutions was determined by using a rheometer (Fungilab, Spain). The turbidity of the working solutions was measured with a turbidimeter (Velp TB1, Italy). The conductivity of the solution was determined by testing its ability to carry an electric current, and conductivity affects the rate of movement of a polymer solution during electrospinning. The electrical conductivities of the solutions to be fed to the electrospinning device were determined with an electrical conductivity meter (WTW MULTI 9310, Germany). Measurement of the viscosity, turbidity and conductivity of the feed solutions were conducted at room temperature $\left(25^{\circ} \mathrm{C}\right)$ triplicate. The results are given as the mean \pm standard deviation of the three measurements. 
FTIR Analysis of Nanofibers

A Fourier Transform Infrared (FTIR) spectrophotometer (Perkin Elmer, USA) was used in order to determine the chemical structure of the surfaces of the nanofibrous matrices. Spectra were recorded with a resolution of 4 $\mathrm{cm}^{-1}$ and at wavelengths of $400-4000 \mathrm{~cm}^{-1}$, and were analyzed using an FTIR software program.

\section{Scanning Electron Microscope Analysis of Nanofibers}

A SEM device (JEOL 840, USA) was used to examine the morphological properties of the nanofibers and to obtain information about their diameters. Small sections of nanofibers on aluminum foil obtained by electrospinning were taken and gold-plated, after which SEM images were obtained. SEM images with 40 $\mathrm{kX}$ enlargement were taken for analysis of the dimensions and morphological characteristics of the nanofibers. The mean diameter value was determined by performing 50 different measurements from the SEM images of each sample.

\section{RESULTS AND DISCUSSIONS}

\section{Analysis of Solutions}

\section{pH Value}

The acidic characteristics and the degree of reactivity of a solution as well as other important characteristics can be determined by a correctly measured $\mathrm{pH}$ value. In addition, many chemical characteristics and processes such as the solubility of a compound are to a large extent connected to the $\mathrm{pH}$ value of the solution. Table 2 shows the $\mathrm{pH}$ values of $20 \%, 25 \%$ and $30 \%$ solutions of collagen hydrolysate. The results of tests performed with a $\mathrm{pH}$ meter showed that solutions of collagen hydrolysate had a weak acidic character with $\mathrm{pH}$ values of between 5.4 and 5.6.

At the isoelectric point of protein there is no net charge on it, whereas above the isoelectric point, the protein should carry a net negative charge. It was observed that fibers with protein are obtained if the $\mathrm{pH}$ of the electrospinning solution is adjusted to the isoelectric point of the protein [31]. The $\mathrm{pH}$ values of the collagen hydrolysate solutions $(\mathrm{pH}$ 5.4-5.6) used in this study were in the range of the isoelectric point of collagen peptides ( $\mathrm{pH} 5-6$ ).

\section{Turbidity Results}

Turbidity test results were used to ascertain whether the solutions had dissolved before electrospinning, and further tests furnished information on the morphology of the nanofibers. Turbidity was measured between 0 and 1000 NTU. The production of homogeneous, continuous and fine solutions is directly related to a turbidity value of 0 NTU. Table 2 gives the turbidity values of collagen hydrolysate solutions. It was determined from tests conducted using a turbidimeter that the solutions were very transparent in appearance and homogeneous. If solutions contain undissolved solid materials, a clear solution is not produced, and the morphology of the nanofibers obtained will not be regular. This can give unwanted results. Turbidity values of between 19.4 and 22.7 NTU were determined for the solutions in the study.

\section{Viscosity Results}

Gelling occurs under the effect of van der Waals forces, with aggregation between particles or molecules in a liquid. The gelling process is studied using rheological measuring techniques. The viscosity characteristics of the solutions in our study were determined in this way. As seen in the Table 2 , mean viscosity values of the solutions at room temperature were found to be generally between 15.4 and $21.0 \mathrm{mPa}$.s. The viscosity values of the collagen hydrolysate solutions were found to increase with increasing $\mathrm{CH}$ concentration, which was resulted in a greater number of polymer chain entanglements within the solution [32]. An increase in the viscosity values of the solutions is undesirable because they become lumpy in the nozzle of the electrospinning apparatus, and this causes the formation of non-homogeneous beaded nanofibers. The viscosity values determined in the study are showed the suitability of solutions with low viscosity values for entanglement to be electrospun.

\section{Conductivity Results}

Electrical conductivity is a parameter which greatly affects the diameter of the nanofibers. Table 2 gives the conductivity values 
of the collagen hydrolysate solutions. These were found to vary between 3.3 and $4.6 \mathrm{mS} / \mathrm{cm}$. In our study, it was observed that conductivity increases with the increase of solution concentration. This situation can be explained by the increase in the total amount of ions in solution. It was thought that an increase in conductivity values by an increase in collagen hydrolysate concentration would make the diameters of the nanofibers obtained low and in this way these values would provide an advantage in the electrospinning process. It has been seen in some studies that solutions with high conductivity produced nanofibers with smaller diameters [33, 34]. However, some other studies support the hypothesis that high conductivity results in fibers with large diameters [35]. The conductivity results obtained in this study contributed to the formation of $\mathrm{CH}$ nanofibers without formation of beads.

Table 2: Properties of collagen hydrolysate solutions

\begin{tabular}{ccccc}
\hline Concentration & $\mathrm{pH}$ & $\begin{array}{c}\text { Turbidity } \\
\text { (NTU) }\end{array}$ & $\begin{array}{c}\text { Viscosity } \\
(\mathrm{mPa} / \mathrm{s})\end{array}$ & $\begin{array}{c}\text { Electrical conductivity, } \\
(\mathrm{mS} / \mathrm{cm})\end{array}$ \\
\hline$\% 20$ & 5.4 & $19.4 \pm 6.7$ & $15.4 \pm 0.3$ & $3.3 \pm 0.4$ \\
$\% 25$ & 5.5 & $20.2 \pm 1.7$ & $17.2 \pm 0.8$ & $4.4 \pm 0.2$ \\
$\% 30$ & 5.6 & $22.7 \pm 3.2$ & $21.0 \pm 0.2$ & $4.6 \pm 0.2$ \\
\hline
\end{tabular}

\section{Characterization of Nanofibers}

\section{FTIR Results}

Figure 2 gives the FTIR spectra of nanofibers obtained from $20 \%-30 \%$ collagen hydrolysate. The graphics obtained are very close to the FTIR spectra of collagen obtained by many other researchers [36-38]. Examining spectra obtained after spectral scans, it was determined that the bands emerging in connection with tension vibration of the (0) C-O, (1) C-O-C, (2) $\mathrm{OR}-\mathrm{C}-\mathrm{C}$, (3) $\mathrm{COO}^{-\mathrm{CH}_{3}}$ (asymmetric), (4) $\mathrm{C}=\mathrm{C}$ and (5) $\mathrm{C}=\mathrm{O}$ groups on the structure chain of the collagen hydrolysate nanofiber samples were at wavenumbers of (0) $1035 \mathrm{~cm}^{-1}, 1082 \mathrm{~cm}^{-1}$ (1) $1064 \mathrm{~cm}^{-1}$, (2) $1140 \mathrm{~cm}^{-1}, 1174 \mathrm{~cm}^{-1}$, (3) 1454 $\mathrm{cm}^{-1}$, (4) $1633 \mathrm{~cm}^{-1}-1647 \mathrm{~cm}^{-1}$, and (5) $1723 \mathrm{~cm}^{-1}$ $1735 \mathrm{~cm}^{-1}$ respectively (Figure 2 ).

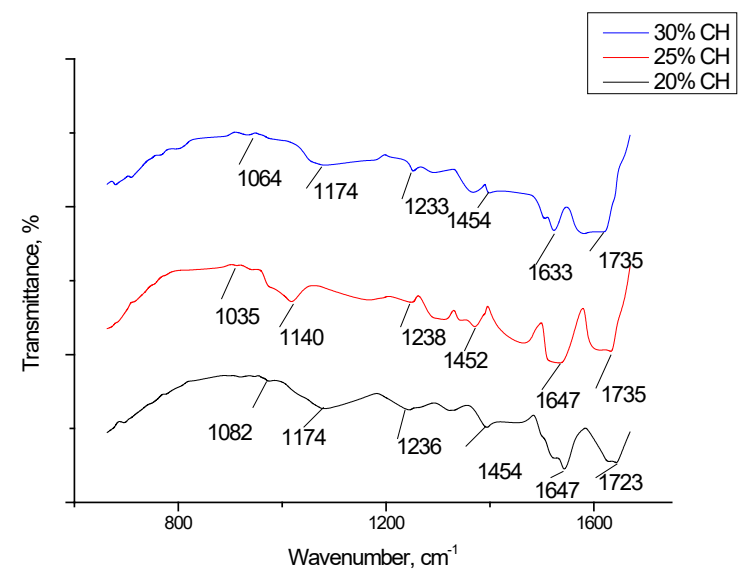

Figure 2. FTIR spectra of collagen hydrolysate nanofibers

In addition, it was determined that in all samples peaks between wavenumbers of $1233 \mathrm{~cm}^{-1}$ and $1236-1237 \mathrm{~cm}^{-1}$ belonged to the amide I band, and those between $1452 \mathrm{~cm}^{-1}$ and $1454 \mathrm{~cm}^{-1}$ belonged to the amide II band. It was observed that the carboxyl band which appeared in connection with the $\mathrm{C}=\mathrm{O}$ absorption band was at wavenumbers of $1723 \mathrm{~cm}^{-1}-1735$ $\mathrm{cm}^{-1}$ in all samples. Absorption bands between $1238 \mathrm{~cm}^{-1}$ and $1452 \mathrm{~cm}^{-1}$ are bands which appear in relation to the existence of a helix structure [37]. Thus FTIR examination showed that the 
helix structures in $\mathrm{CH}$ nanofibers obtained could be preserved without destruction.

\section{Results from the Scanning Electron Microscope}

Figure 3 shows $40 \mathrm{kX}$ magnified SEM images of nanofibers obtained from 20\%, 25\% and $30 \%$ collagen hydrolysate solutions. It was seen that the diameters of the nanofibers obtained as a result of 2 hours spinning of a $20 \%$ collagen hydrolysate solution varied between $111 \mathrm{~nm}$ and $273 \mathrm{~nm}$, while the nanofibers obtained as a result of 3 hours' spinning of a
$20 \%$ solution of $\mathrm{CH}$ had diameters of $103 \mathrm{~nm}$ to $384 \mathrm{~nm}$. The nanofibers obtained from a $25 \%$ collagen hydrolysate solution after 2 hours of electrospinning had diameters of $116 \mathrm{~nm}-133$ $\mathrm{nm}$, and after 3 hours of electrospinning $157 \mathrm{~nm}$ $235 \mathrm{~nm}$. With a $30 \% \mathrm{CH}$ solution, the diameters of the nanofibers obtained were $140 \mathrm{~nm}-313 \mathrm{~nm}$ with 2 hours of electrospinning and $176 \mathrm{~nm}-260$ $\mathrm{nm}$ with 3 hours. It was determined from SEM images that the smallest diameter of nanofibers obtained from $\mathrm{CH}$ solutions of $20 \%-30 \%$ was 103 $\mathrm{nm}$, and the largest was $384 \mathrm{~nm}$.

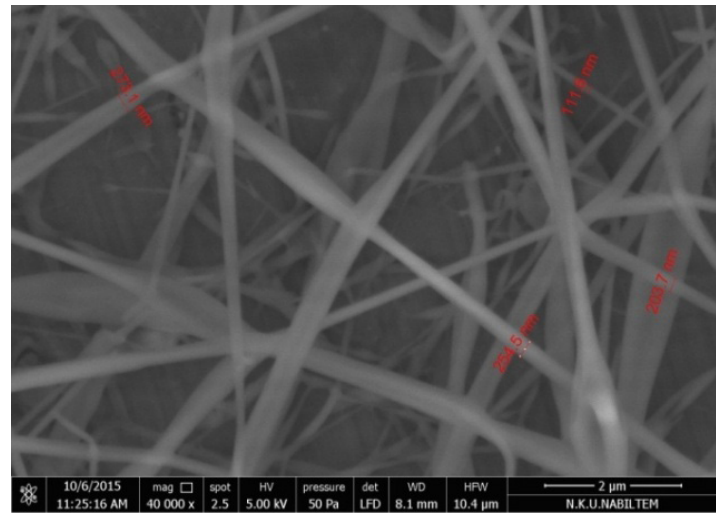

$20 \% \mathrm{CH}$ nanofibers (2 hours spinning)

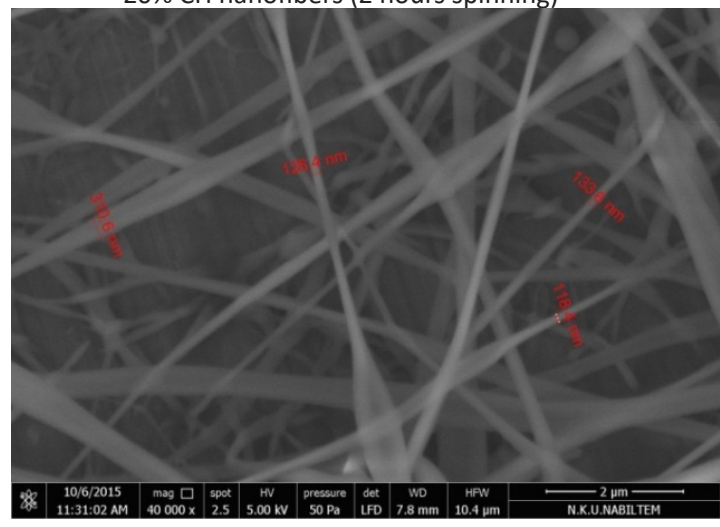

$25 \% \mathrm{CH}$ nanofibers (2 hours spinning)

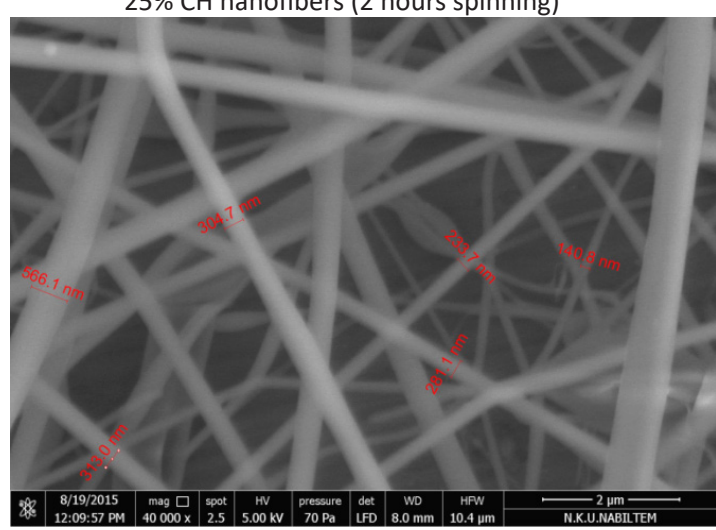

$30 \% \mathrm{CH}$ nanofibers (2 hours spinning)

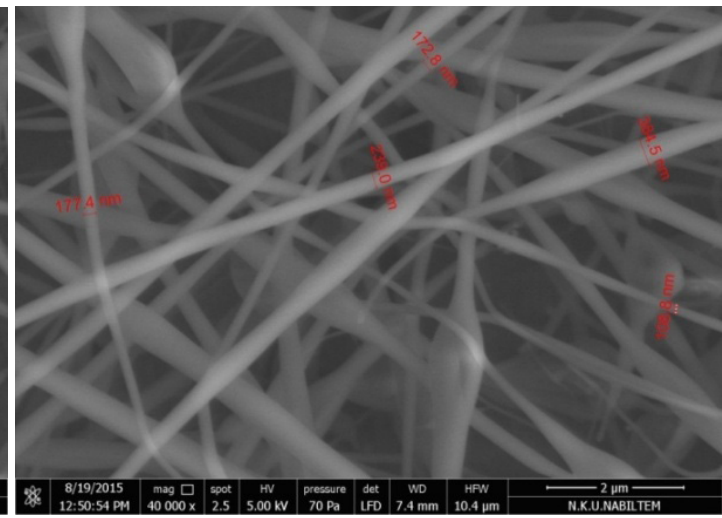

$20 \% \mathrm{CH}$ nanofibers (3 hours spinning)

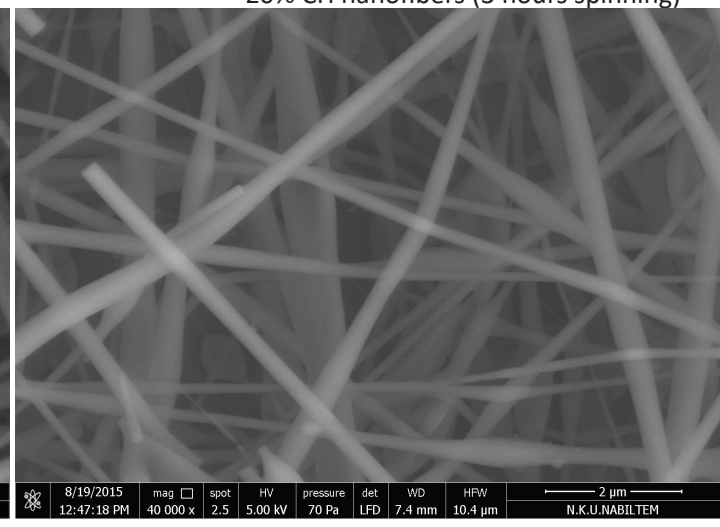

$25 \% \mathrm{CH}$ nanofibers (3 hours spinning)

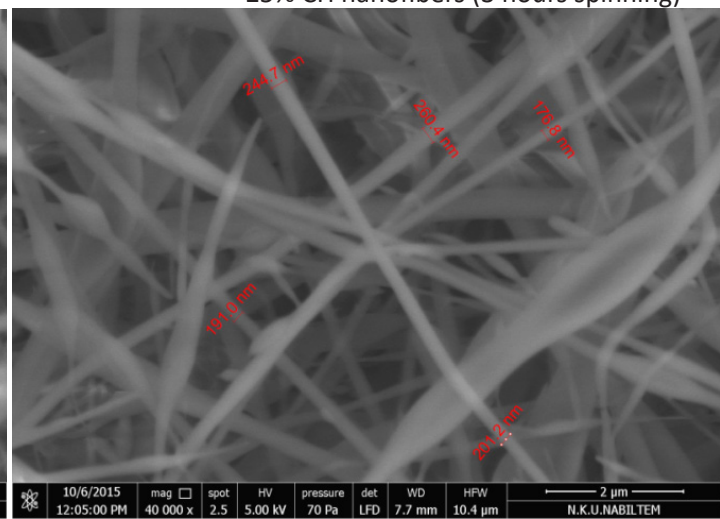

$30 \% \mathrm{CH}$ nanofibers (3 hours spinning)

Figure 3. SEM images of nanofibers obtained from $20 \%, 25 \%$ and $30 \%$ solutions of $\mathrm{CH}$ 
In previous studies conducted on collagen, nanofibers in the range of 100-700 $\mathrm{nm}$ in diameter were obtained [23, 24, 39, 40 ], but when collagen hydrolysate mixed with chitin derivate and polyvinyl alcohol was used, nanofibers of between $200 \mathrm{~nm}$ and $600 \mathrm{~nm}$ were obtained [30]. In the present study, collagen hydrolysate nanofibers with small diameters of 103 nm-384 nm were obtained using no other material than a solvent. It is thought that more homogeneous nanofibers could be obtained in future studies by adding salt and large-molecule polymers or a plasticizer.

\section{CONCLUSIONS}

In conclusion, collagen hydrolysate nanofibers were successfully produced by the electrospinning method. First, it was determined that the $10 \%, 15 \% \mathrm{CH}$ solutions beaded, $20 \%$, $25 \%$ and $30 \% \mathrm{CH}$ solutions used had $\mathrm{pH}$ values of 5.4-5.6, viscosities of 15.4-21.0 mPa.s, turbidities of 19.4-22.7 ntu, and conductivities of 3.3-4.6 $\mathrm{mS} / \mathrm{cm}$ according to concentration. This clearly showed that nanofibers can be obtained from collagen hydrolysate at concentrations of between $20 \%$ and $30 \%$. Studies are being carried out in many different scientific fields today in connection with the potential advantages of using collagen hydrolysate to develop new products and materials containing collagen which can be put to various different uses. In the light of the results of the present study, nanofibers obtained by the use of collagen hydrolysate can be accepted as a new collagenic material, and after improvement and development in future studies, will form a new material of industrial and economic importance. This also provides an alternative opportunity to make use of collagen hydrolysate, a solid waste of the leather industry, which will also provide ecological benefits.
Acknowledgements

This study was supported by Pamukkale University Scientific Research Projects Coordination Unit as Beginning Level Research Project No. 2014 BSP 008.

\section{REFERENCES}

1. Huang, Z.M., Zhang, Y.Z., Kotaki, M., Ramakrishna, S., A review on polymer nanofibers by electrospinning and their applications in nanocomposites, Compos Sci Technol, 2003, 63, 15, 2223-2253, https://doi. org/10.1016/S0266-3538(03)00178-7.

2. Almetwally, A.A., El-Sakhawy, M., Elshakankery, M.H., Kasem, M.H., Technology of Nano-Fibers: Production Techniques and Properties - Critical Review, Journal of the Textile Association, 2017, 78, 1, 5-14.

3. Ramakrishna, S., Fujihara, K., Teo, W., Lim, T., Ma, Z. (Eds.), An introduction to electrospinning and nanofibers, World Scientific Publishing Co. Pte. Ltd., Singapore, 2005, 396 p, https:// doi.org/10.1142/9789812567611.

4. Doshi, J., Reneker, D.H., Electrospinning process and application of electrospun fibers, J Electrostat, 1995, 35, 151-160, https://doi. org/10.1016/0304-3886(95)00041-8.

5. Teo, W.E., Ramakrishna, S., A review on electrospinning design and nanofibre assemblies, Nanotechnology, 2006, 17, 89-106, https://doi.org/10.1088/09574484/17/14/R01.

6. Andrady, A.L., Science and technology of polymer nanofibers, John Wiley \& Sons, New Jersey, 2008, 403 p, https://doi. org/10.1002/9780470229842.

7. Demir, M.M., Yılgör, i., Yılgör, E., Erman, B., Electrospinning of polyurethane fibers, Polymer, 2002, 43, 11, 3303-3309, https:// doi.org/10.1016/S0032-3861(02)00136-2.

8. Khill, M.S., Bhattarai, S.R., Kim, H.Y., Kim, 
S.Z., Lee, K.H., Novel fabricated matrix via electrospinning for tissue engineering, J Biomed Mater Res Part B: Appl Biomater, 2005, 72B, 117-124, https://doi.org/10.1002/ jbm.b.30122.

9. Safi, S., Morshed, M., Ravandi, H.S.A., Ghiachi, M., Study of electrospinning of sodium alginate, blended solutions of sodium alginate/poly(vinyl alcohol) and sodium alginate/poly(ethylene oxide), J Appl Polym Sci, 2007, 104, 5, 3245-3255, https://doi. org/10.1002/app.25696.

10. Lu, J.W., Zhu, Y.L., Guo, Z.X., Hu, P., Yu, J., Electrospinning of sodium alginate with poly(ethylene oxide), Polymer, 2006, 47, 23, 8026-8031, https://doi.org/10.1016/j. polymer.2006.09.027.

11. Noh, H.K., Lee, S.W., Kim, J.M., Oh, J.E., Kim, K.H., Chung, C.P., Choi, S.C., Park, W.H., Min, B.M., Electrospinning of chitin nanofibers: degradation behavior and cellular response to normal human keratinocytes and fibroblasts, Biomaterials, 2006, 27, 21, 3934-3944, https://doi.org/10.1016/j. biomaterials.2006.03.016.

12. Kim, C.W., Kim, D.S., Kang, S.Y., Marquez, M., Joo, Y.L., Structural studies of electrospun cellulose nanofibers, Polymer, 2006, 47, 14, 5097-5107, https://doi.org/10.1016/j. polymer.2006.05.033.

13. Kenawy, E.R., Abdel-Hay, F.I., El-Newehy, M.H., Wnek, G.E., Controlled release of ketoprofen from electrospun poly(vinyl alcohol) nanofibers, Mater Sci Eng, 2007, 459, 1-2, 390-396, https://doi.org/10.1016/j. msea.2007.01.039.

14. Kim, B., Park, H., Lee, S.H., Sigmund, W.M., Poly(acrylic acid) nanofibers by electrospinning, Mater Lett, 2005, 59, 7, 829-832, https://doi.org/10.1016/j. matlet.2004.11.032.
15.Piperno, S.,Lozzi, L., Rastelli, R., Passacantando, M., Santucci, S., PMMA nanofibers production by electrospinning, Appl Surf Sci, 2006, 252, 15, 5583-5586, https://doi.org/10.1016/j. apsusc.2005.12.142.

16. Zheng, J., He, A., Li, J., Xu, J., Han, C.C., Studies on the controlled morphology and wettability of polystyrene surfaces by electrospinning or electrospraying, Polymer, 2006, 47, 20, 7095-7102, $\quad$ https://doi.org/10.1016/j. polymer.2006.08.019.

17. Li, L., Belan, L.M., Craighead, H.G., Frey, M.W., Formation and properties of nylon-6 and nylon-6/montmorillonite composite nanofibers, Polymer, 2006, 47, 17, 6208-6217, https://doi.org/10.1016/j. polymer.2006.06.049.

18. Harmancıoğlu, M., Dikmelik, Y., Structure, composition and properties of raw hide, Özen Ofset, Izmir (in Turkish), 1993.

19. Aslan, A., Gülümser, G., Opportunities to benefit from collagen outside the leather industry, I. National Leather Symposium Proceedings Book, İzmir (in Turkish), 2004.

20. Clemente, A., Enzymatic protein hydrolysates in human nutrition, Trends Food Sci Techn, 2000, 11, 254, https://doi.org/10.1016/ S0924-2244(01)00007-3.

21. Huang, Z.M., Zhang, Y.Z., Ramakrishna, S., Lim, C.T., Electrospinning and mechanical characterization of gelatin nanofibers, Polymer, 2004, 45, 5361-5368, https://doi. org/10.1016/j.polymer.2004.04.005.

22. Zhang, Y.Z., Venugopal, J., Huang, Z.-M., Lim, C.T., Ramakrishna, S., Crosslinking of the electrospun gelatin nanofibers, Polymer, 2006, 47, 2911-2917, https://doi. org/10.1016/j.polymer.2006.02.046.

23. Matthews, A.J., Wnek, G.E., Simpson, D.G., Bowlin, G.L., Electrospinning of collagen nanofibers, Biomacromolecules, 2002, 3, 232- 
238, https://doi.org/10.1021/bm015533u.

24. Rho, K.S., Jeong, L., Lee, G., Seo, B-M., Park, Y.J., Hong, S.-D., Roh, S., Cho, J.J., Park, W.H., Min, B-M., Electrospinning of collagen nanofibers: Effects on the behavior of normal human keratinocytes and early-stage wound healing, Biomaterials, 2006, 27, 1452-1461, https:// doi.org/10.1016/j.biomaterials.2005.08.004.

25. Zeugolis, D.I., Khew, S.T., Yew, E.S.Y., Ekaputra, A.K., Tong, Y.W., Yung, L-Y.L., Hutmacher, D.W., Sheppard, C., Raghunath, M., Electrospinning of pure collagen nano-fibres Just an expensive way to make gelatin?, Biomaterials, 2008, 29, 2293-2305, https:// doi.org/10.1016/j.biomaterials.2008.02.009.

26. Buttafoco, L., Kolkman, N.G., Buijtenhuijs, P.E., Poot, A.A., Dijkstra, P.J., Vermes, I., Feijen, J., Electrospinning of collagen and elastin for tissue engineering applications, Biomaterials, 2006, 27, 724-734, https://doi.org/10.1016/j. biomaterials.2005.06.024.

27. Chen, Z., Mo, X., Quing, F., Electrospinning of Collagen-Chitosan Complex, Mater Lett, 2006, 61, 16, 3490-3494, https://doi. org/10.1016/j.matlet.2006.11.104.

28. Chen, J.P., Chang, G.Y., Chen, J.K., Electrospun collagen/chitosan nanofibrous membrane as wound dressing, Colloid Surf A Physicochem Eng Asp, 2008, 313, 314, 183-188, https:// doi.org/10.1016/j.colsurfa.2007.04.129.

29. Meng, L., Arnoult, O., Smith, M., Wnek, G.E., Electrospinning of in situ crosslinked collagen nanofibers, J Mater Chem, 2012, 22, 1941219417, https://doi.org/10.1039/c2jm31618h.

30. Kovalenko, G.M, Bokova, E.S., Filatov, E.Yu., Mirontseva, V.V., Electrospun fibrous materials made of collagen and chitin derivatives, Fibre Chem, 2016, 48, 6, 466-469, https://doi.org/10.1007/s10692-017-9818-6.

31. Tang, C., Ozcam, E., Stout, B., Khan, S.A., Effect of $\mathrm{pH}$ on Protein Distribution in
Electrospun PVA/BSA Composite Nanofibers, Biomacromolecules, 2012, 13, 1269-1278, https://doi.org/10.1021/bm2017146.

32. Niehues, E., Quadri, M.G.N., Spinnability, morphology and mechanical properties of gelatins with different bloom index, Braz J Chem Eng, 2017, 34, 01, 253261, https://doi.org/10.1590/01046632.20170341s20150418.

33. Fong, H., Chun, I., Reneker, D.H., Beaded nanofibers formed during electrospinning, Polymer, 1999, 40, 16, 4585-4592, https:// doi.org/10.1016/S0032-3861(99)00068-3.

34. Kim, S.J., Lee, C.K., Kim, S.I., Effect of Ionic Salts on the Processing of Poly(2- acrylamido-2methyl-1-propane sulfonic acid) Nanofibers, $J$ Appl Polym Sci, 2005, 96, 1388-1393, https:// doi.org/10.1002/app.21567.

35. Yener, F., Comparison of nano fibers obtained by classical and needleless electrospinning methods and effects of system parameters in these methods on fiber, M.Sc. Thesis, Süleyman Demirel University, Isparta (in Turkish), 2010.

36. Muyonga, J.H., Cole, C.G.B., Duodu, K.G., Characterization of acid soluble collagen from skins of young and adult Nile perch (Lates nilotics), Food Chem, 2004, 85, 81-89, https:// doi.org/10.1016/j.foodchem.2003.06.006.

37. Liu, H.Y., Li, D., Guo, S.D., Studies on collagen from the skin of channel catfish (Ictalurus punctaus), Food Chem, 2007, 101, 2, 621-625, https://doi.org/10.1016/j. foodchem.2006.01.059.

38. Yan, M., Li, B., Zhao, X., Ren, G., Zhuang, Y., Hou, H., Zhang, X., Chen, L., Fan, Y., Characterization of acid-soluble collagen from the skin of walleye pollock (Theragra chalcogramma), Food Chem, 2008, 107, 1581-1586, https://doi.org/10.1016/j. foodchem.2007.10.027. 
39. Dong, B., Arnoult, O., Smith, M.E., Wnek, G.E., Electrospinning of Collagen Nanofiber Scaffolds from Benign Solvents, Macromol Rapid Commun, 2009, 30, 539-542, https:// doi.org/10.1002/marc.200800634.

40. Rath, G., Hussain, T., Chauhan, G., Garg, T., Goyal, A.K., Collagen nanofiber containing silver nanoparticles for improved wound healing applications, J Drug Target, 2016, 24, 6, 520-529, https://doi.org/10.3109/106118 6X.2015.1095922.
(C) 2019 by the author(s). Published by INCDTPICPI, Bucharest, RO. This is an open access article distributed under the terms and conditions of the Creative Commons Attribution license (http://creativecommons.org/licenses/by/4.0/). 